This article was downloaded by: [Memorial University of Newfoundland]

On: 31 January 2015, At: 21:38

Publisher: Routledge

Informa Ltd Registered in England and Wales Registered Number: 1072954

Registered office: Mortimer House, 37-41 Mortimer Street, London W1T

3J H, UK

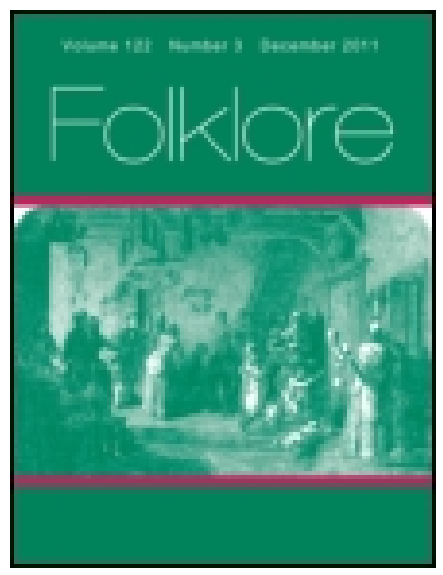

\title{
Folklore
}

Publication details, including instructions for authors and subscription information:

http:// www. tandfonline.com/loi/ rfol20

\section{Cropping Animals' Ears.}

N. W. Thomas

Published online: 06 Feb 2012.

To cite this article: N. W. Thomas (1901) Cropping Animals' Ears., Folklore, 12:1, 97-97, DOI: 10.1080/0015587X.1901.9719614

To link to this article: http:// dx. doi. org/ 10.1080/0015587X.1901.9719614

\section{PLEASE SCROLL DOWN FOR ARTICLE}

Taylor \& Francis makes every effort to ensure the accuracy of all the information (the "Content") contained in the publications on our platform. However, Taylor \& Francis, our agents, and our licensors make no representations or warranties whatsoever as to the accuracy, completeness, or suitability for any purpose of the Content. Any opinions and views expressed in this publication are the opinions and views of the authors, and are not the views of or endorsed by Taylor \& Francis. The accuracy of the Content should not be relied upon and should be independently verified with primary sources of information. Taylor and Francis shall not be liable for any losses, actions, claims, proceedings, demands, costs, expenses, damages, and other liabilities whatsoever or howsoever caused arising directly or indirectly in connection with, in relation to or arising out of the use of the Content.

This article may be used for research, teaching, and private study purposes. Any substantial or systematic reproduction, redistribution, reselling, loan, sub-licensing, systematic supply, or distribution in any form to anyone is 
expressly forbidden. Terms $\&$ Conditions of access and use can be found at http://www.tandfonline.com/page/terms-and-conditions 
"Can you move now?" asked he. "Yes," said the ogre. Then he knocked another nail in. "Can you move now ?" "A little." Then a third nail. "Can you move now?" "Not a bit." "That's right," said Thirteen. "I am Thirteen," said he, and nailed down the rest of the lid, and carried the ogre in the box to the king.

The King decreed that the ogre should be roasted after they had had a look at him; and the six brothers said "Our brother who nailed the box down must open it." So they heated a large oven, and Thirteen went and opened the box, and out jumped the ogre; but before he was well out Thirteen got out of the way, and the ogre went for the six brothers and gobbled them up. Then he saw Thirteen and chased him; but Thirteen dodged him skilfully; and at length he so managed that the clumsy ogre in trying to catch him fell head foremost into the oven, and thus he was roasted.

Then the king gave Thirteen his daughter in marriage and made him heir of his kingdom.

W. R. Paton.

\section{Cropping Animals' Ears.}

(Vol. xi., p. 456.)

Cream-stealing cats have their left ears cut off in the Highlands. Stewart, 'Truixt Ben Nevis and Glencoe, p. 238.

Among precautions against witchcraft, "as soon as a calf is dropt they immediately lacerate the ear by slitting it with a knife." (Neighbourhood of Helmsley.) BRAND, iii., 20, 21 , quoting The Yorkshireman, 1846.

"Chats entiers vont au sabat le samedi ; mais si l'on leur avait coupé de la queue ou des oreilles, ils n'y seraient jamais admis." Dumaine, 'Tinchebray, p. 585 , n. I 12.

"Lorsqu'on conduit une vache au taureau, on ne manque jamais pour la faire concevoir .... . de fendre en quatre la dernière articulation de sa queue." La Sicotière: Le Département de POrne, p. 339.

"Einem neugekauften Pferde wird im Frühjahr aus dem Schweif etwas Blut genommen, und dasselbe dem Thiere eingegeben .... damit es dableiben möge." . Holzmayer, Osiliana, p. rog.

N. IV. Thomas.

vol. XII. 